\title{
Student Mobility and Learning Opportunities: \\ Travelling to Southeast Asia
}

\author{
Ismail Suardi Wekke \\ Southeast Asia Academic Mobility (SEAAM) \\ Email: iswekke@gmail.com
}

Kuliah Umum

Sekolah Tinggi Ilmu Ekonomi AMKOP

Makassar; 30 Desember 2019

\begin{abstract}
ABSTRAK
Kertas kerja sebagai gambaran awal untuk pelaksanaan Student Mobility 2020. Dijadwalkan pelaksanaan 3 s.d. 14 Desember 2020 dengan tiga negara tujuan Malaysia, Thailand, dan Singapura. Pembiayaan dilaksanakan swadaya, dengan tidak ada pembayaran sama sekali untuk pelaksanaan program.
\end{abstract}

Keywords: student mobility; jaringan kerjasama; seaam;

\section{Pendahuluan}

Di tahun 2019 dilaksanakan $2^{\text {nd }}$ Student Mobility selama sepuluh hari, dimulai dari Kuala Lumpur sampai ke Singapura. Diikuti 107 orang dengan tujuh perguruan tinggi (Wekke, 2019). Setelah evaluasi, diputuskan untuk kembali melaksanakan Student Mobility 2020 untuk seri ketiga sebagaimana sudah terlaksana 2018 dan 2019. Diantara rangkaian awal Student Mobility adalah Student Colloquium (Wekke \& Jaafar, 2019). Kertas kerja ini sebagai gambaran awal pelaksanaan Student Mobility 2020 yang akan dilaksanakan 3 s.d. 14 Desember 2020 di Asia Tenggara.

\section{Gambaran Singkat}

2018 kali pertama dilaksanakan Student Mobility dengan aktivitas utama di University College of Yayasan Pahang. Selanjutnya kembali diprakarsai Institut Agama Islam Negeri Parepare melalui program studi Tadris Bahasa Inggris untuk 2019 dengan bersama-sama kembali UCYP (Mujahidah \& Wekke, 2019). Pada 28 November s.d. 8 Desember 2019, bersama-sama dengan mitra seperti University College of Yayasan Pahang, Malaysia; Fatoni University, Thailand; Universiti Teknikal Malaysia Melaka, Malaysia; diselenggarakan forum yang memberi kesempatan bagi dosen dan mahasiswa untuk mempresentasikan makalah, artikel hasil penelitian, proposal tesis, atau tesis. Begitu pula terdapat tiga kali kesempatan untuk mengunjungi perpustakaan yaitu perpustakaan Universiti Pendidikan Sultan Idris, Malaysia; Universiti Sultan Zainal Abidin, Malaysia; dan ISEAS, Singapura. 


\section{Jadwal Kegiatan}

Masing-masing peserta berangkat dari lokasi masing-masing di Indonesia dan bertemu di Kuala Lumpur, Malaysia.

\begin{tabular}{|l|l|l|}
\hline \multicolumn{1}{|c|}{ Hari \& Tanggal } & \multicolumn{1}{c|}{ Kegiatan } & Keterangan \\
\hline Kamis, 3 Desember 2020 & Tiba di Kuala Lumpur & \\
\hline Jumat, 4 Desember 2020 & Tiba di Kuantan, Pahang & \\
\hline Sabtu, 5 Desember 2020 & Student Colloquium & UCYP \\
\hline Ahad, 6 Desember 2020 & Perjalanan ke UniSZA & \\
\hline Senin, 7 Desember 2020 & UniSZA & \\
\hline Selasa, 8 Desember 2020 & Perjalanan ke Pattani & \\
\hline Rabu, 9 Desember 2020 & Pattani & \\
\hline Kamis, 10 Desember 2020 & Perjalanan ke Kuala Lumpur & \\
\hline Jumat, 11 Desember 2020 & Melaka dilanjutkan ke Singapura & \\
\hline Sabtu, 12 Desember 2020 & Singapura & \\
\hline Ahad, 13 Desember 2020 & Pulang & \\
\hline Senin, 14 Desember 2020 & Pulang & \\
\hline
\end{tabular}

\section{Konstruksi Teoritis}

Pelaksanaan Student Mobility menjadi salah bagian program Erasmus yang menjadi jaringan di benua Eropa. Verbik \& Lasanowski (2007) mengemukakan adanya pola dan juga kecenderungan peningkatan program ini. Lembaga atau institusi mulai bertambah dan membentuk jaringan yang semakin luas (Murphy-Lejeune, 2003). Salah satu bagian yang mendasari dimana terdapat ruang kelas yang beragam dan dengan keluasan jangkauan geografis (Lash \& Kirkpatrick, 1990). Baik dosen maupun staf, dan juga mahasiswa memandang bahwa pelaksanaan Student Mobility menjadi pendukung pengembangan perguruan tinggi (Kasalak, 2013). Ini menunjukkan bahwa program Student Mobility sudah dikenal dan dilaksanakan serta menjadi program pengembangan di perguruan tinggi Eropa.

Perguruan tinggi memiliki kesempatan untuk pengembangan jaringan dan kerjasama. Namun, diperlukan strategi pengembangan dan juga kemampuan eksekusi program (Wekke, Kahar, \& Amri, 2018). Pelaksanaan Student Mobility akan berkontribusi bagi akreditasi perguruan tinggi (Almana, \& Saeka, \& Wekke, 2018). Sementara presentasi dan workshop juga memberi penguatan bagi kejujuran akademik (Ardinansyah, Tenrisau, Aslim, \& Wekke, 2018). Setidaknya, dengan keberadaan Student Mobility akan menjadi bagian dalam akselerasi perguruan tinggi Indonesia di kawasan Asia Tenggara. Sementara di Asia Tenggara, pelaksanaan academic mobility tidak dilembagakan secara formal sebagaimana di Eropa. Sehingga prakarsa SEAAM akan menjadi awal dalam memperluas jaringan kerjasama di regional Asia Tenggara. 


\section{Pembiayaan}

Komponen biaya terdiri dari 1) dokumen perjalanan seperti passport; 2) tiket pesawat; 3) penginapan/hotel; 4) bis atau transportasi; dan 5) makan. Untuk passport dapat dicek biaya sesuai ketentuan imigrasi. Sementara tiket dan penginapan dapat dilihat di pelbagai platform seperti Travelola, Tiket, dll. Untuk bis disiapkan kurang lebih RM 40-50/hari untuk perjalanan antar kota atau lintas negara. Sementara makan di Malaysia berkisar RM 5-10.

\section{Penutup}

Kertas kerja ini merupakan gambaran awal. Sehingga perencanaan baik teknis, maupun operasional perlu didiskusikan kembali. Paling tidak, dengan kertas kerja ini menjadi panduan awal untuk merencanakan kegiatan yang bisajadi akan menjadi bagian dalam rencana kerja perguruan tinggi.

\section{Daftar Pustaka}

Almana, L. O., \& Saeka, S. \& Wekke, I. S. (2018). Tata Kelola Perguruan Tinggi Berbasis Akreditasi. Yogyakarta: Deepublish.

Ardinansyah, A., Tenrisau, D., Aslim, F., \& Wekke, I. S. (2018). Ketidakjujuran Akademik Dalam Pendidikan Tinggi. https://doi.org/10.31227/osf.io/tp9vg.

Kasalak, G. (2013). Views of academic staff on Erasmus teaching staff mobility: The case of Akdeniz University. Journal of Higher Education and Science, 3(2), 133-141.

Lash, A. A., \& Kirkpatrick, S. L. (1990). A classroom perspective on student mobility. The Elementary School Journal, 91(2), 177-191.

Mujahidah, M., \& Wekke, I. S. (2019). Initiatives on Learning Through Student Mobility. Zenodo. http://doi.org/10.5281/zenodo.3595083.

Murphy-Lejeune, E. (2003). Student mobility and narrative in Europe: The new strangers. Routledge.

Verbik, L., \& Lasanowski, V. (2007). International student mobility: Patterns and trends. World Education News and Reviews, 20(10), 1-16.

Wekke, I. S., Kahar, M. S., \& Amri, I. (2018). Perguruan Tinggi Tanah Papua dan Strategi Pengembangan Pendidikan Tinggi. https://doi.org/10.31227/osf.io/m3kvb.

Wekke, I. S., \& Jaafar, A. (2019). International Student Colloquium. Zenodo. http://doi.org/10.5281/zenodo.3568972.

Wekke, I. S. (2019). 2nd Student Mobility in Southeast Asia 2019. Zenodo. http://doi.org/10.5281/zenodo.3568894. 